\title{
Landmark Preservation Laws: Compensation for Temporary Taking
}

States and municipalities are presently enacting, at a rapidly increasing rate, statutes and ordinances to preserve individual historic structures. ${ }^{1}$ This comment will analyze these laws in order to determine whether the governmental restrictions, imposed to provide public bodies with time in which to effect measures to preserve the landmark, constitute valid regulatory controls of land or represent unconstitutional takings of property without just compensation. ${ }^{2}$

Early legislation dealing with landmarks centered on the creation of historic districts through the employment of zoning regulations. ${ }^{3}$ Although the constitutionality of these enactments has been questioned, the courts have consistently sustained them as valid police power measures designed to promote the public welfare. ${ }^{4}$ The body of statutory

1 E.g., Los Angeles, Cal., Ordinance 121,971, April 30, 1962; NEW YORK, N.Y., ADMIN. Code ch. 8A (Supp. 1967); Phiradelphia, PA., Code § 14-2008 (1956). For a general compilation of historic preservation statutes and ordinances, see J. MORRISON, Historic PresERVATION LAW 61-186 (2d ed. 1965).

2 The line between a valid regulation of private property and a taking of private property without just compensation is by no means distinct. Generally, property may be regulated-without compensation-if the restrictions are based on the police power of the state to protect the health, safety, morals, and general welfare of the public through the prohibition of injurious uses of private property. See I P. Nichols, EMINENT Domain § 1.42[2] (3d rev. ed. J. Sackman 1964); Village of Euclid v. Ambler Realty Co., 272 U.S. 365 (1926); A. Dunham, Modern Real Estate Transactions 35-40 (2d ed. 1958). A taking involves appropriation of the property, or an interest therein, for public use or enjoyment and, under the fourteenth amendment and state constitutional due process clauses, gives rise to the owner's right to just compensation for the lost property interest. 1 P. Nichors, supra. Regulation not justified by the police power may so deprive an owner of the use and enjoyment of his property that it effectively constitutes an unconstitutional taking of the property without compensation. E.g., Pennsylvania Coal Co. v. Mahon, 260 U.S. 393 (1922).

3 E.g., Mass. ANn. Laws ch. 40C, §§ I-13 (1966); NEw OrLeAns, LA., Code ch. 65 (1956); NEW YORK, N.Y., ADMIN. CODE ch. 8A (Supp. 1967); Providence, R.I., Zoning Ordinance ch. 1342, August 5, 1960; SAnTa Fe, N.M., Code ch. 28 (1953). See Note, The Police Power, Eminent Domain, and the Preservation of Historic Property, 63 Colum. L. REv. 708, 713-14 (1963).

4 Although it is difficult to argue that historic district laws fall within the scope of traditional police power control of health, safety, and morals, it is possible to sustain these enactments under two elements of the broader concept of general welfare. First, there is some support for the use of zoning regulations to promote aesthetic objectives, State ex rel. Saveland Park Holding Corp. v. Wieland, 269 Wis. 262, 69 N.W.2d 217, cert. denied, 350 U.S. 841 (1955), and, to a certain extent, aesthetic considerations have been 
law governing historic districts is, therefore, based on favorable judicial precedent and, to the extent that new statutes are patterned on older enactments, they appear certain to be sustained as a permissible exercise of the police power. ${ }^{5}$

In many cities, however, structures of obvious architectural and historic value stand as isolated landmarks that cannot easily be included in historic districts. ${ }^{6}$ To preserve these structures, some cities have adopted statutes directed toward individual landmarks. Although each of these enactments displays a varying approach, a basic pattern is apparent. Initially, a public agency is empowered to designate appropriate structures as landmarks. ${ }^{7}$ If the owner of a designated landmark wishes to alter or to demolish his property, he must inform the agency and apply for permission to do so. Should it object to the alteration or demolition, ${ }^{8}$ the public body may deny the permit for a period of from three to six months. During this time, the agency may undertake steps to preserve the structure, either by convincing the owner that he should not change the landmark, by persuading an appropriate governmental body to exercise its power of eminent domain, or by finding a private group that is willing to purchase the structure and preserve it. If the agency, at the end of the delay period, fails to develop a preservation plan, it must allow the owner to proceed with demolition. ${ }^{9}$

upheld as a basis for historic district laws. Opinion of the Justices to the Senate, 333 Mass. 773, 128 N.E.2d 557 (1955). Second, and more importantly, the ideal of general welfare includes the economic benefits resulting from the stabilization of property values and the increase in tourist revenues in an historic district. City of New Orleans v. Pergament, 198 La. 852, 5 So. 2 d 129 (1941); Opinion of the Justices to the Senate, supra. For a discussion of the validation of police power control of historic districts on the grounds of economic benefit as an element of general welfare, see Note, supra note 3, 63 Coluxr. L. REv. at 715-16.

5 Note, supra note 3, 63 Colum. L. REv. at 732.

6 Wolf, The Landmark Problem in New York, 22 N.Y.U. INTRA. L. REv. 99, 102 (1967).

7 Because of dissimilarities in architectural styles and historic periods, the guidelines for determining appropriate structures vary widely: Los Angeles, Cal., Ordinance 121,971, April 30, 1962 (buildings, site or structures of importance or significance in the cultural, economic or social history of the city, state or nation, or identified with historic events or persons); NEW YORK, N.Y., ADMIN. CODE ch. 8A, \& 207-1.OK (Supp. 1967) (any improvement, any part of which is thirty years old or older, which has a special character or special historical or aesthetic interest or value as part of the development, heritage or cultural characteristics of the city, state or nation); Phildoelphis, PA., Code $\S 14-2008$ (1956) (historic buildings which are important to the education, culture, traditions, and economic values of the city).

8 Since preservation agencies have the responsibility of protecting landmarks, it would seem to follow that they are required to object to the demolition of any structure which they have designated as having historic importance. Nevertheless, the agencies' powers of objection are usually discretionary. See, e.g., NEW YoRk, N.Y., ADMIN. CODE ch. 8A, $\S \S 207-1.0 \mathrm{~b}, 207-6.0 \mathrm{~b}$ (Supp. 1967).

8 In most cities, the statutes envision a simple procedure for applying their provisions. 
The most important elements of the preservation statutes authorize agencies to prevent the alteration or demolition of privately owned structures while the public attempts to preserve the landmark. Since these laws have not, for the most part, been construed by the courts, they can most readily be analyzed by reference to other instances in which public agencies, without recourse to a zoning enactment, have restrained the rights of owners to improve or change the use of private property.

\section{Prohibition of Arteration or Demolition}

There are two major lines of cases in which governmental restrictions similar to those permitted by the landmarks enactments have been challenged in the courts: ( 1 ) those situations in which public bodies have prevented the development of private property because it may later be appropriated by the public-so-called "freezing" cases; (2) those instances involving building "set-back" requirements."11 Although roughly analogous factual situations occur in each line of cases, the courts have struck down the activities involved in the "freezing" cases as takings of property without just compensation and have

In Charleston, South Carolina, the Board of Architectural Review may postpone the demolition of pre-1860 structures for not less than three months to consult with the city council and private groups about possible preservation measures. CHARLESTON, S.C., CODE ch. 49, art. X, $\$ 49-46$ (1959). The Philadelphia Historical Commission may postpone demolition of designated landmarks for up to six months while it consults civic groups and public agencies to ascertain how the structure can be preserved. PhLAdelphiA, PA., CoDe § 14-2008 (1956). When the Los Angeles Cultural Heritage Board has designated an historic site as a landmark, no demolition may be undertaken without the Board's approval. Demolition permits may be suspended for thirty to 180 days to allow the Board time to take steps to preserve the structure. If it cannot do so, the owner may proceed without the Board's approval. Los Angeles, Cal., Ordinance 121,971, April 30, 1962. The procedure in New York, while analogous to that in other cities, is much more complex. NEW YORR, N.Y., ADMIN. CODE ch. 8A, § 207-8.0 (Supp. 1967).

10 Forster v. Scott, 136 N.Y. 577, 32 N.E. 976 (1893); State ex rel. Mumma v. Stansberry, 5 Ohio App. 2d 191, 214 N.E.2d 684 (1964); State ex rel. Dillie Laboratories Corp. v. Woditsch, 106 Ohio App. 541, 156 N.E.2d 164 (1958); Henle v. City of Euclid, 97 Ohio App. 258, 125 N.E.2d 355, appeal dismissed per curiam, 162 Ohio St. 280, 122 N.E.2d 792 (1954); Miller v. City of Beaver Falls, 368 Pa. 189, 82 A.2d 34 (1951).

11 Headley v. City of Rochester, 272 N.Y. 197, 5 N.E.2d 198 (1936); Rochester Business Inst., Inc. v. City of Rochester, 25 App. Div. 2d 97, 267 N.Y.S.2d 274 (1966); Roer Constr. Corp. v. City of New Rochelle, 207 Misc. 46, 136 N.Y.S.2d 414 (Sup. Ct. 1954); Vangellow v. City of Rochester, 190 Misc. 128, 71 N.Y.S.2d 672 (Sup. Ct. 1947); State ex rel. Miller v. Manders, 2 Wis. $2 d$ 365, 86 N.W.2d 469 (1957).

"Set-back" laws enable cities to enact official street maps showing the location of proposed but unopened streets as well as existing ways that will eventually be widened. An owner whose property abuts on one of these streets cannot obtain a building permit for an improvement that will encroach on land lying in the bed of a proposed street unless he can show that the restrictions cause a substantial decrease in the value of and fair return from his land. See, e.g., N.Y. GeN. Crry LAW $\$ 35$. 
upheld the "set-back" requirements as valid regulation of private property.

The circumstances involved in the "freezing" cases arise after an administrative agency refuses to issue a building permit to improve property that may be condemned, ${ }^{12}$ or a legislative body enacts a statute which, on its face, does not prohibit the development of the land, but instead denies compensation for improvements made after the government designates the property for possible appropriation. ${ }^{13}$ These restraints on development may last for a definite ${ }^{14}$ or an indefinite ${ }^{15}$ period of time. During the time that the public restricts the property, the owner finds himself in a position of discharging the responsibilities asssociated with the possession of property-such as paying taxes ${ }^{16}$ without being allowed the free use of his land. ${ }^{17}$

Even though the public does not attempt to exercise physical dominion over the land, some courts have taken the position that:

Whenever a law deprives the owner of the beneficial use and free enjoyment of his property, or imposes restraints upon such use and enjoyment, that materially affect its value, without legal process or compensation, it deprives him of his property within the meaning of the Constitution. ${ }^{18}$

In the absence of a valid justification for regulation, such as the prevention of injurious uses of private property, most courts, realizing that "[a]ll that is beneficial in property arises from its use and the fruits of that use,"19 have consistently held that the governmental actions in the "freezing" cases were unconstitutional takings of private property. ${ }^{20}$

12 State ex rel. Mumma v. Stansberry, 5 Ohio App. 2d 191, 214 N.E.2d 684 (1964); State ex rel. Dillie Laboratories Corp. v. Woditsch, 106 Ohio App. 541, 156 N.E.2d 164 (1958).

13 Forster v. Scott, 136 N.Y. 577, 32 N.E. 976 (1893); Miller v. City of Beaver Falls, 368 Pa. 189, 82 A.2d 34 (1951).

14 Miller v. City of Beaver Falls, $368 \mathrm{~Pa} .189,82$ A.2d 34 (1951) (three years from passage of original ordinance).

15 Forster v. Scott, 136 N.Y. 577, 32 N.E. 976 (1893) (until the city decides to appropriate the land).

16 Henle v. City of Euclid, 97 Ohio App. 258, 264, 125 N.E.2d 355, 358 (1954).

17 Admittedly, zoning restrictions may prevent an owner from using property in the manner in which he chooses, note 2 supra, but none of the cases under discussion here involves the restraint of property through the employment of a general zoning ordinance, nor do the agencies attempt to justify their actions on the ground that the proposed use would be inimical to the public health, safety, morals, or general welfare.

18 Forster v. Scott, 136 N.Y. 577, 584, 32 N.E. 976, 977 (1893). The Pennsylvania Supreme Court, in Miller v. City of Beaver Falls, $368 \mathrm{~Pa} .189,197,82$ A.2d 34, 38 (1951), quoted this language as support for the invalidation of a "freezing" action.

19 Forster v. Scott, 136 N.Y. 577, 584, 32 N.E. 976, 977 (1893); Miller v. City of Beaver Falls, 368 Pa. 189, 197, 82 A.2d 84, 38 (1951). Accord, State ex rel. Mumma v. Stansberry, 5 Ohio App. 2d 191, 194, 214 N.E.2d 684, 686 (1964).

20 Forster v. Scott, 136 N.Y. 577, 584, 32 N.E. 976, 977 (1893) ("Whenever a law deprives 
The broad statement that owners are deprived of an inherent right to "the beneficial use and free enjoyment" of their property, however, does not satisfactorily isolate the elements of the taking. Although some courts have argued generally that the owner was deprived of the "use" of the property, ${ }^{21}$ he has clearly not been denied all of the "use," since holding the land as a vacant lot would, in a sense, make "use" of it. More specifically, however, the underlying facts in each of these cases shows that the owner was actually deprived of the right to "build" on his land.22 The courts which have considered the "freezing" of private property, then, have invalidated public actions substantially like those authorized by the landmark preservation laws ${ }^{23}$ - the denial of an owner's right to "build" on or improve his property, even though he may maintain the existing "use" of the land.

A second element of the "freezing" cases which some courts have attacked is the actual or potential loss of economic value resulting from the restrictions on the property. ${ }^{24}$ If, like courts, rational purchasers are interested in an owner's right to "build" on property, ${ }^{25}$ restricted land would not be in great demand and might even be "practically unsalable." 26 Thus, in the cases in which private property is "frozen" -just as in those instances in which public agencies might impose controls upon landmarks-the owner's right to alienate his property would

the owner of the beneficial use and free enjoyment of his property ... without legal process or compensation, it deprives him of his property within the meaning of the constitution."). Accord, State ex rel. Dillie Laboratories Corp. v. Woditsch, 106 Ohio App. 541, 542, 156 N.E.2d 164, 166 (1958); Henle v. City of Euclid, 97 Ohio App. 258, 264, 125 N.E.2d 355, 358 (1954). See generally 2 P. Nichols, Eminent Domain §§ 6.3, 6.4 (3d rev. J. Sackman ed. 1964).

21 See cases cited note 20 supra.

22 State ex rel. Mumma v. Stansberry, 5 Ohio App. 2d 191, 214 N.E.2d 684 (1964) (owner denied building permit for improvement and alteration of structure on his land); State ex rel. Dillie Laboratories v. Woditsch, 106 Ohio App. 541, 156 N.E.2d 164 (1958) (owner denied permit to erect new structure on his land); Henle v. City of Euclid, 97 Ohio App. 258, 125 N.E.2d 355 (1954) (owner denied permit to build gas station on vacant lot); Miller v. City of Beaver Falls, $368 \mathrm{~Pa}$. 189, 82 A.2d 34 (1951) (owner denied compensation for houses erected on vacant land which city might later condemn).

23 See note 9 supra.

24 Forster v. Scott, 136 N.Y. 577, 584-85, 32 N.E. 976, 977 (1893) ("[A]s this circumstance [deprivation of the owner's right to build on his property] obviously impaired its value and interfered with his power of disposition, it [the statute] was to that extent void as to him .... .'); State ex rel. Mumma v. Stansberry, 5 Ohio App. 2d 191, 194, 214 N.E.2d 684,686 (1964) ("[T] the value of property is dependent upon its actual or potential use."). 25 See note 22 and accompanying text supra.

26 Miller v. City of Beaver Falls, 368 Pa. 189, 194, 82 A.2d 34, 36 (1951); accord, Forster v. Scott, 136 N.Y. 577, 32 N.E. 976 (1893) (potential purchaser refused to accept deed to land because of restrictions on building); Henle v. City of Euclid, 97 Ohio App. 258, 125 N.E.2d 355 (1954) (oil company would purchase property only if it could obtain permission to build gas station). 
be abridged because he could sell only to those persons not interested in changing the land. In addition, the owner who chose to sell would suffer a financial loss because the lack of a competitive market demand for the property would tend to depress its price. ${ }^{27}$

Loss of economic value suggests a further, although implicit, reason for judicial invalidation of the public activity presented in the "freezing" cases. Because the market value of restricted property is depressed, an owner is faced with the prospect of reduced "just compensation" should the public decide to appropriate his land..$^{28} \mathrm{It}$ is possible that some courts have opposed the imposition of nonregulatory controls because they believe that the public should not be allowed to benefit by awarding artificially depressed compensation as a result of its own actions. ${ }^{29}$

In the building "set-back" cases, cities have enacted official street maps showing the location of proposed but unopened streets as well as existing ways that will eventually be widened. An owner whose property abuts on one of these streets cannot obtain a building permit for an improvement that will encroach on land lying in the bed of a proposed street unless he can show that the restrictions cause a substantial decrease in the value of and fair return from his land. ${ }^{30}$ Since the "setback" laws also authorize governmental controls on private property without compensation to the owner, the decisions upholding them will bring the concepts set forth in the "freezing" cases into clear relief.

27 In a more abstract sense, "value" may also be related to the "use" of the land. If "beneficial use and free enjoyment" is a right unto itself, there may be some inherent noneconomic "value" to an owner who possesses the power to deal freely with his Iand.

28 When there is an ascertainable market value, courts have traditionally employed it as a measure for determining the amount of compensation to be awarded in eminent domain proceedings. When the market value is not available, the judiciary has relied on so-called actual, or "intrinsic," value, which may be based on such factors as original cost, assessed value, or sales of comparable property. 4 P. Nichors, EMINENT Domarn § 12.1, at 17-21 (3d rev. ed. J. Sackman 1962). At best, if the controls imposed on property destroy the market, the compensation will be artificial when compared to the possibility that an award might have been based on a known market value demand for developable land. See United States v. Miller, 317 U.S. 369, 374-75 (1945). If the factors influencing the court are original cost or assessed value, the amount may even be very low.

29 In none of the cases involving "freezing" have the courts expressly stated that the public's activities were invalidated on these grounds. In Henle v. City of Euclid, 97 Ohio App. 258, 125 N.E.2d 355 (1954), however, the argument was advanced that the cost of appropriating land would be substantially decreased if building on the property was prevented. The court merely noted the position in its concluding paragraph, as it struck down the "freezing." Cf. Congressional School of Aeronautics, Inc. v. State Roads Comm'n, $218 \mathrm{Md}$. 236, 241, 146 A.2d 558, 560-61 (1958) (zoning ordinance cannot be used as a substitute for eminent domain by depressing property values and thereby reducing amount to be paid upon appropriation).

30 E.g., N.X. GeN. GiTY LAW § 35. 
Like the sweeping language classifying the activities involved in the "freezing" cases as takings of property without just compensation, broad terms have been employed to uphold "set-back" requirements as "regulatory in character . . . intended for a public purpose and to advance the general welfare."' 31 This description is a conclusion, however, and the constituent elements of these activities must be examined to determine why "set-back" restrictions have been sustained.

"Set-back" requirements have been sustained if, despite the imposition of restrictions on a portion of the land, the property can still be reasonably used as the owner chooses. ${ }^{32}$ On the other hand, restrictions making it impracticable for an owner to employ his property as he had planned, although he might be able to use the land in another way, have been struck down. ${ }^{33}$ Even though the "set-back" laws may prevent improvement of land abutting on a mapped street, they cannot be employed to deny an owner his right to freely develop the bulk of his property.

A second redeeming factor of the "set-back" laws is a "saving clause" which empowers the public agency to grant a building permit in those instances in which "the land within such mapped street or highway is not yielding a fair return on its value to the owner." 34 Under this provision, controls causing minimal economic loss due to increased cost to develop land or decreased income from improvements have been

31 Roer Constr. Corp. v. City of New Rochelle, 207 Misc. 46, 50, 136 N.Y.S.2d 414, 417 (Sup. Ct. 1954).

32 In Headley v. City of Rochester, 272 N.Y. 197, 5 N.E.2d 198 (1936), a property owner challenged the constitutionality of an official street map, filed pursuant to state statute, showing the proposed widening of an avenue upon which his land abutted. The court refused to rule on the validity of the law because the owner could not show that the restrictions on building in any way damaged his present use of the property as a residence, and he did not allege any change in use which might be affected by the restrictions. See Rochester Business Inst., Inc. v. City of Rochester, 25 App. Div. 2d 97, 267 N.X.S.2d 274 (1966) where, despite a "set-back" requirement causing the owner to suffer a 7.1 per cent land loss, he could still erect a proposed office building with substantially the same floor space, with a cost increase of only six per cent, by adding one or two more floors.

33 In Roer Constr. Corp. v. City of New Rochelle, 207 Misc. 46, 136 N.Y.S.2d 414 (Sup. Ct. 1954), the court held an amended street map to be an unconstitutional interference with property rights when it included almost all of the property upon which the owner had planned to build an apartment building within the bed of a proposed highway. See also Vangellow v. City of Rochester, 190 Misc. 128, 71 N.Y.S.2d 672 (Sup. Ct. 1947). But see State ex rel. Miller v. Manders, 2 Wis. 2d 365, 86 N.W.2d 469 (1957) ("set-back" requirement upheld and building permit denied even though most of the owner's property lay within the boundaries of a proposed street).

34 N.Y. GEN. CrTY LAW $\$ 35$. It is instructive to note that Forster v. Scott, 196 N.Y. 577, 32 N.E. 976 (1893), a case in which the New York Court of Appeals found an unconstitutional taking of property without compensation (see text accompanying note 18 supra), involved an early version of the official map law which did not contain a "saving clause." 
upheld ${ }^{35}$ while restrictions that would substantially decrease the economic value of or income from property have been struck down. ${ }^{36}$ "Setback" requirements are valid only to the extent that the owner suffers no substantial loss in the value of his property, a position guaranteed by the existence of a "saving clause."

It has been suggested that a valid objective of the "set-back" laws is the limitation of any damage that might occur, both to the public and to the landowner, if the property were appropriated for street purposes. $^{37}$ Although this appears to be an express affirmation of the use of public restrictions to depress the value of private property, there are two definite limitations on this power. First, by the terms of the "saving clauses," the public cannot prevent development when the return from or the value of the land is impaired. Second, the courts have upheld the restrictions only when they have prevented the free use of a small portion of the property and not when they have prohibited full development of a large part of the land. ${ }^{38}$ Thus, the saving of public funds is, in a sense, a by-product of the building "set-back" laws and can occur only if the owner's interests have first been protected.

In view of the three major issues-ability of a landowner to build upon and improve all of his property, protection of economic value, and the employment of governmental power to minimize the cost of public appropriation-analyzed by the courts in the "freezing" and "set-back" cases, landmark preservation statutes authorize public actions amounting to takings of private property without just compensation.

First, and most importantly, these laws prevent the owner from changing the use of his property during the period in which a public agency searches for a means of preservation. ${ }^{39}$ The restriction goes to the entire tract of land upon which the historic structure stands and not just a portion thereof. Since courts are interested in the ability of an owner to build on his property, ${ }^{40}$ the fact that the landmark statutes permit the owner to retain the structure and use it in the existing man-

35 Rochester Business Inst., Inc. v. City of Rochester, 25 App. Div. 2d 97, 267 N.Y.S.2d 274 (1966).

30 Vangellow v. City of Rochester, 190 Misc. 128, 71 N.Y.S.2d 672 (Sup. Ct. 1947). The importance of maintaining the value of land is even more apparent in those decisions where courts have sustained "set-back" requirements which confer an economic benefit on an owner. Thus, "set-back" laws may be upheld because they increase the value of an owner's property by assuring him easy access to it. Headley v. City of Rochester, 272 N.Y. 197, 5 N.E.2d 198 (1936).

37 See State ex rel. Miller v. Manders, 2 Wis. 2d 365, 376, 86 N.W.2d 469, 475 (1957).

38 Notes $32-33$ and accompanying text supra.

39 Note 9 and accompanying text supra.

40 Note 22 and accompanying text supra. 
ner is not significant. The owner is deprived of the right of free use and enjoyment because he cannot build upon and improve his property as he chooses, and thus an important element of a taking is created. ${ }^{41}$

Second, because the public will not allow change or improvement, the market for the property may disappear-or at least be constrictedwith a consequent impairment of the owner's right of alienation and a decline in the value of the land. ${ }^{42}$ In addition, the landmark property may be deteriorating and expensive to maintain. The statutes, however, have no counterpart for the "saving clause" in the "set-back" laws, ${ }^{43}$ so the owner is faced with the possibility of substantial economic loss with no possibility of relief.

Third, although agencies may not be attempting to benefit the public by reducing acquisition costs of historic property, if the imposition of controls depresses the market value of the land, public funds will be saved in subsequent appropriation proceedings. If the reduction of public expenditures can occur only after the owner's development and economic rights are protected, ${ }^{44}$ then any argument that the statutes save public funds must fall because those rights are severely impaired.

The landmark preservation statutes, which empower public agencies to develop preservation schemes while withholding alteration or demolition permits, display features similar to those struck down in the "freezing" cases: the prohibition of building upon or improvement of property, a decline in the economic value of land, and the saving of condemnation funds as a result of public restriction. At the same time, those elements which led to the validation of "set-back" requirements -the ability of the owner to continue to use his property as he chooses

41 Notes 19-22, 32-33 and accompanying text supra.

42 Notes 24-27 and accompanying text supra.

43 E.g., N.Y. GEN. CTrY LAw \& 35; notes 31-33 and accompanying text supra. Although N.Y. GEN. CIrY LAws $\S 20(25-2)$ authorizes local bodies to remit real estate taxes to the owners of historic structures, the provision in NEW YoRK, N.Y., ADMIN. CoDE ch. 8A, $\S 207-8.0$ (Supp. 1967), is designed to effect a permanent scheme whereby the owner may preserve the property and is not intended to be applied to the economic loss caused by the temporary prohibition of alteration or demolition. To the extent that an owner accepts a rebate of taxes as an inducement to maintain his structure, the allowance will function somewhat like a "saving clause" by reducing challenges to the constitutionality of the prohibitions on demolition placed on specific parcels of property. If an owner contests the amount of the rebate as insufficient, however, the judiciary will be forced to assess the award. Since it is questionable whether the rebate formula would be upheld as a just award for appropriated property, see Wolf, The Landmark Problem in New York, 22 INTRA. L. REv. 99, 107-108 (1967), the courts will probably turn to a scheme like that presented in Part II infra in order to determine what an owner's just compensation should be. In addition, the rebate of taxes is not primarily designed to provide the public with a temporary period in which to decide whether and how a given landmark can be savedone of the major objectives of the preservation laws.

44 Notes $37-38$ and accompanying text supra. 
and the existence of the "saving clause" to insure a fair return on the property-are not present. It follows that the preservation statutes authorize takings of property for which the owner must be compensated.

\section{Compensation for Restrictions on Alteration or Demolition}

Since landmark preservation laws authorize public agencies to impose controls and restrictions that constitute a taking of private property, without providing compensation to the owner, they appear to be unconstitutional on their face. It is possible, however, that these statutes could be sustained if a method can be devised to reimburse an owner for losses suffered during the period in which the property is regulated. Thus, both the public's need for time to work out a method of preserving a landmark and the owner's constitutional right to just compensation for a taking of his property could be satisfied.

Following the restriction of the landmark, public agencies must pursue one of two alternatives: (1) they can develop a plan whereby the structure is preserved through public or private appropriation, or (2) should they fail to effect a means of maintaining the landmark, the agencies must remove the controls and permit the owner to proceed with alteration or demolition. ${ }^{45}$ Assuming that the public must select one of these two alternatives, it is possible to establish a scheme of payment that will compensate the owner for any losses incurred through the imposition of regulations on his property.

If public or private bodies condemn the property, an owner is constitutionally guaranteed just compensation for his land from the time at which it is taken. ${ }^{46}$ In order to ensure to the owner a just award, two elements of compensation must be satisfied: first, the amount must be based on the fair market value of the property ${ }^{47}$ immediately prior to the time it is restricted; ${ }^{48}$ and second, the owner must be made whole from the initial point at which the taking occurred ${ }^{49}$ - the time at which the landmark was restricted.

By paying the owner the fair market value of his property before its alteration or demolition was prevented, any changes in the value of the land resulting from the actions of the landmark agency would be elimi-

45 See notes 7-9 and accompanying text supra.

46 See U.S. Consr. amend. V; United States v. Miller, 317 U.S. 369 (1943); Scott v. United States, 146 F.2d 131 (5th Cir. 1944); Foster v. City of Detroit, 254 F. Supp. 655 (E.D. Mich. 1966).

474 P. Nichols, Eminent Domain \& 12.1 at 17-21 (3d rev. ed. J. Sackman 1962).

48 See United States v. Miller, 317 U.S. 369 (1943); Foster v. City of Detroit, 254 F. Supp. 655 (E.D. Mich. 1966).

40 See Seaboard Air Line Ry. v. United States, 261 U.S. 299 (1923). 
nated.50 The public could derive no benefit from its own restrictions when it finally condemns the property. The owner, on the other hand, would not be relegated to the position of receiving only the worth of the property as an historic landmark without regard to any higher value which the market might place on the land because of unrealized, but potential, utilization. ${ }^{51}$

Since the right to compensation arises at the time at which property is taken, ${ }^{52}$ any award must include an amount to cover the loss of the property between the time that it is taken and the time that compensation is actually paid. This result is generally achieved by paying an owner statutory interest on the fair market value of the property, beginning at the time of taking. ${ }^{53}$ The interest is not merely a return on the condemnation award, but rather is an equivalent of the use of the property lost through the appropriation. ${ }^{54}$

The theory that treats interest as an equivalent of use gives rise to a further consideration. Restrictions imposed on property pursuant to landmark enactments are not a physical invasion of the land and do not prevent an owner from occupying the structure. An owner who remains in possession of historic property, therefore, may not be entitled to an equivalent of use of the land as an element of his compensation. ${ }^{55}$

50 United States v. Miller, 317 U.S. 369 (1943); Gity of Detroit v. Cassese, 376 Mich. 311. 136 N.W.2d 896 (1965).

51 In addition, it should be relatively easy to ascertain the fair market value of the property before the imposition of controls-easier, perhaps, than determining the worth of the property as a landmark. Assuming that the market assigns a higher value to the best use of a piece of property than to any other, the fact that a rational owner requests permission to destroy a landmark in order to alter the present utilization of the land suggests that an active market is making demands for a better use of the property which should be capable of ascertainment. At the same time, there may be no market demands for the property employed as a landmark, a fact that would make the determination of its fair market value somewhat more difficult.

52 See Seaboard Air Line Ry. v. United States, 261 U.S. 299 (1923).

53 Id.

54 United States v. Certain Land in the City of St. Louis, 41 F. Supp. 809 (E.D. Mo. 1941), aff'd sub nom. O'Donnell v. United States, 131 F.2d 882 (8th Cir. 1942). The rule that interest is an equivalent of use may originally have developed because the courts felt that an owner should be made whole for his losses during the period between appropriation of property and actual payment, even though statutory interest did not normally run against the government on unliquidated debts. In re Post Office Site in Borough of the Bronx, 210 F. 832 (2d Cir. 1914). By relying on the terms of the constitutional guarantee that "property shall not be taken without just compensation, the courts were able to develop the fiction that an equivalent for the use of the taken property could be given, for which the statutory interest rate, based on fair market value, seemed to be a reasonable measure, without upsetting the rule restricting interest on unliquidated claims. Seaboard Air Line Ry. v. United States, 261 U.S. 299 (1923). Thus, whatever the rule on interest running on unliquidated claims against the government may presently be, the doctrine that interest in eminent domain cases is an equivalent for use still stands.

55 Courts appear to be in conflict over compensation for the time between a taking 
The loss to which the owner is being subjected by the taking, however, is not of the occupation of the property in its existing state, but of that better use available through alteration or demolition. If we assume that the fair market value of the unrestricted property on which the statutory interest is to be based is greater than the value of the site as a controlled landmark because it reflects a better use to which the property might be put, ${ }^{56}$ then it is clear that an owner should be allowed to recover a larger sum which reflects his real loss of the equivalent of use of the unrestricted property, rather than being given only that value attributable to possession of the existing structure. In order to ensure that the owner does not receive more than the equivalent of use of the uncontrolled property, however, the value of his occupation of the landmark should be set off against the amount of the statutory interest on the fair market value of the unrestricted property. ${ }^{57}$

Thus, in those instances in which the public chooses to condemn the property, the owner should be compensated for the taking by means of a formula which allows him the fair market value of the unrestricted property, plus statutory interest from the point at which the controls were imposed set off by an amount attributable to his possession of the restricted property.

If public agencies are unable to develop a plan to preserve a landmark, they must allow the owner to proceed with alteration or demolition. The property is lost for only a limited time-the period when

and the actual award if the owner remains in possession of the property. Annot., 36 A.L.R.2d 458 (1954). Compare United States v. Certain Property in Borough of Manhattan, 266 F. Supp. 764 (S.D.N.Y. 1967) (owner entitied to equivalent of use and possession of the property), with Foster v. City of Detroit, 254 F. Supp. 655 (E.D. Mich. 1966) (value of possession of property is set off against equivalent of use), and United States v. Certain Land in City of St. Louis, 41 F. Supp. 809 (E.D. Mo. 1941) (owner cannot recover equivalent of use for periad while he was in passession).

56 See note 51 and accompanying text supra.

57 See CAL. Crv. Proc. CODE $\$ 255 \mathrm{~b}(\mathrm{~b})$. Admittedly, the application of this set-off formula may involve two variables based on differing premises. The statutory interest rate applied to the fair market value before the imposition of controls is an estimate of the equivalent of the use of the property. The possessory value of the landmark, especially in instances where the property is rented, may often be the actual amount. If the primary concern, however, is to secure just compensation for the owner of taken property, then the object must be to guarantee him the equivalent of use of the land without regard to government restrictions, a figure which courts feel is best approximated by the statutory interest rate in those cases where the owner is not, in fact, able to develop the land to its highest and best potential. The fact that an actual figure is used as a set-off has no real effect on this formula except as it prevents the owner from receiving more than just compensation. If the owner could prove that he suffered an economic loss during the period of restriction, the actual figure might be very important, since it would seem that the amount of the loss should be added to the estimated equivalent of use of the unregulated land in order to assure full just compensation for the taking. 
controls are in force. Although the owner is still constitutionally guaranteed compensation, in this case he is entitled only to an award for a limited loss of the property and not for a permanent appropriation.

The interest usually condemned in temporary taking cases is possessory..$^{58}$ In these instances, courts have determined just compensation by awarding an amount based on the fair market rental value of the property, ${ }^{59}$ the normal measure of a possessory interest of limited duration.

Unlike most temporary taking cases, however, the restrictions on landmarks effectively appropriate a nonpossessory interest in the land. The controls, which do not prevent an owner's continued occupation of the structure, are in the nature of an easement that, for shorthand, might be termed an easement of development rights. ${ }^{60}$

The fact that landmark preservation statutes authorize the taking of an easement raises additional considerations in the valuation of the temporary taking. Courts have traditionally determined the amount to be awarded for appropriated easements by reference to the "before and after" rule. 11 The value of an easement is determined by subtracting: from the fair market value of the property immediately before the taking of the easement, the fair market value of the property immediately after the interest is appropriated. The rule is necessitated by the diffculty of determining any market value, let alone a fair one, for easements which are not readily bought and sold. ${ }^{62}$ Although this method of valuation may not show the actual worth of the interest, ${ }^{63}$ the "before and after" rule may be the only way of approximating just compensation.

In cases where an easement of development rights is taken through the imposition of controls on an historic structure, courts should determine its value by applying the "before and after" rule. The amount thus determined would represent the value of the easement in fee. But again, since the easement is taken for only a limited period, it would

68 Kimball Laundry Co. v. United States, 338 U.S. 1 (1949). But cf. Pomeroy v. State, 18 Misc. 2d 377, 191 N.Y.S.2d 84 (Sup. Ct. 1959).

59 E.g., Kimball Laundry Co. v. United States, 338 U.S. 1 (1949).

60 For cases considering similar easements, see, e.g., South v. Texas E. Transmission Corp. 332 S.W.2d 442 (Tex. Civ. App. 1960); Kamrowski v. State, 31 Wis. 2d 256, 142 N.W.2d 793 (1966); Klump v. Cybulski, 274 Wis. 604, 81 N.W.2d 42 (1957).

61 Olson v. United States, 292 U.S. 246 (1934); United States v. Welch, 217 U.S. 333 (1910); United States ex rel. TVA v. Easement and Right-of-way Over 1.0 Acre of Land, More or less, in Madison Cnty, 248 F. Supp. 702 (W.D. Tenn. 1965); Tennessee Gas Transmission Co. v. Maze, 45 N.J. Super. 496, 133 A.2d 28 (App. Div. 1957).

62 See Tennessee Gas Transmission Co. v. Maze, 45 N.J. Super. 496, 133 A.2d 28 (App. Div. 1957). But see West, Condemnation of Limited Use Easements, 1964 INST. oN EMINENT DOMAIN 109.

63 See West, supra note 62. 
be an unwarranted benefit to the owner to pay him its fee value. Instead, the owner has lost the use of this easement of development rights for a temporary period. Therefore, the owner should be awarded the statutory interest rate on the fee value of the easement-an amount which would approximate an equivalent of the lost use $^{64}$-for the period during which restrictions were placed on the historic structure. ${ }^{65}$

\section{ConcLusion}

The recent landmark preservation laws clearly authorize public actions amounting to unconstitutional takings of private property. This conclusion, however, need not retard the trend toward preservation of historic structures if the rights of the owner to just compensation for a taking of his property are protected. If the owner is awarded the fair market value of his unrestricted land plus the equivalent of his lost use when the landmark is permanently appropriated, or is given the equivalent of the use of an easement of development rights when alteration or demolition is merely prevented for a period of time, his right to compensation for a lost property interest will be satisfied. Moreover, the public will gain valuable time in which to develop a means of preserving endangered historical monuments.

64 Notes 53-57 and accompanying text supra. If, after removal of the restrictions, an owner can show that the fair market value of the property is lower than its worth prior to the imposition of controls, it would appear that the regulations have permanently deprived him of part of his property interest. For instance, increased construction costs or rising interest rates during the period of regulation may have permanently diminished the market demands which originally induced the owner to request permission to change the structure. If this is true, then the owner should be allowed to recover this decrease in the fair market value of the land-the permanent easement-as well as the equivalent of the use of the temporary easement of development rights.

65 There are, perhaps, two alternative methods of determining the compensation to be awarded for the temporary taking of an easement. First, the traditional method of compensating a temporary taking, note 59 supra, could be applied by awarding the owner the fair market rental value of the easement. As suggested in the text, however, there may be no market for renting easements, and, therefore, there would be no basis for determining this value. Second, since it would appear that what the owner has actually lost is the interest attributable to the use and enjoyment of the development of the property over and above its utilization as a landmark, he could theoretically be made whole by awarding him statutory interest on the fee value of the taken parcel of property, determined before the imposition of controls, set off by an amount attributable to the equivalent of his actual use and enjoyment of the historic property during the period of the restrictions.

It should be noted that this is exactly the formula applied to make the award retroactive in those cases in which the public actually condemns the land. See notes 53-57 and accompanying text supra. A somewhat complex formula, based on the value of the whole fee and involving two differing variables, however, obscures the fact that compensation is being paid for an easement, and not an estate, in land. In addition, this method would be more difficult to apply-because of the necessity of proving more elementswithout necessarily giving more accurate results. 